\title{
Biogeographic and nearshore-offshore trends in isotope ratios of intertidal mussels and their food sources around the coast of southern Africa
}

\author{
J. M. Hill*, C. D. McQuaid, S. Kaehler \\ Coastal Research Group, Department of Zoology and Entomology, Rhodes University, PO Box 94, Grahamstown 6140, \\ South Africa
}

\begin{abstract}
There are broad differences in oceanography and primary production around the southern African coast that are likely to give rise to major differences in trophic pathways. Stable isotope ratios provide integrated information on trophic relationships, yet there has been limited research on geographic variation in isotopic composition of marine consumers and their food. In this study, $\delta^{13} \mathrm{C}$ and $\delta^{15} \mathrm{~N}$ of suspended particulate matter (SPM), intertidal mussels and common macroalgae along the southern African coastline were explored. Nearshore-offshore isotope trends as well as biogeographic and temporal patterns in isotopic ratios of mussel tissue, macroalgae and SPM were investigated at 12 sites along the coast from Namibia to the Mozambique border. SPM exhibited overall trends of nearshore ${ }^{13} \mathrm{C}$ depletion from south-west to north-east along the coastline and from nearshore $(0 \mathrm{~km})$ to offshore $(10 \mathrm{~km})$ waters, in both cases suggesting a shift from a nearshore signature strongly influenced by macroalgal detritus to one more representative of oceanic phytoplankton. With one exception it was possible, using discriminant analysis, to categorize mussel populations into 4 geographic groups, on the basis of both carbon and nitrogen signatures: the east coast, the southeast coast, the south-west coast and the west coast. Macroalgae showed no consistent biogeographic trends and need to be examined in greater detail to relate nearshore SPM values to living macroalgal signatures. A linear mixing model indicated that mussels along the entire coastline generally demonstrated more than $50 \%$ dependence on nearshore carbon and nitrogen, emphasizing the importance of nearshore primary production to intertidal consumers.
\end{abstract}

KEY WORDS: $\delta^{13} \mathrm{C} \cdot \delta^{15} \mathrm{~N} \cdot$ Stable isotope analysis $\cdot$ Biogeographic trends $\cdot$ Mussels $\cdot$ Diet

\section{INTRODUCTION}

Variation in coastal hydrography plays an important role in intertidal community ecology. Nearshore conditions of coastal waters have significant effects on intertidal benthic organisms (Blanchette et al. 2005), and several studies have shown strong correlations between coastal oceanography and nearshore benthic community structure (e.g. Menge et al. 1999, Nielsen \& Navarrete 2004). Because of biogeographic variation of nearshore hydrography, the influence of coastal water extends beyond the effects on recruitment rates that are a present focus of attention (Alexander \& Roughgarden 1996, McQuaid \& Lawrie 2005), and includes effects on the nature of the food available to primary consumers, especially suspension feeders. This coupling of oceanographic conditions and nearshore community structure has significant implications for the southern African shoreline, which is influenced by both the Benguela and the Agulhas current systems (McQuaid \& Payne 1998), implying biogeographic differences in the food resources available to intertidal communities. The Agulhas current, along the east and south coasts, brings warm, oligotrophic water from the Mozambique channel (Lutjeharms et al. 2000), while the Benguela current flows northwards along the west coast bringing cold eutrophic water of Antarctic origins (Andrews \& Hutchings 1980). 
Broad geographic and possibly temporal differences therefore exist in the oceanography, pelagic primary production (Andrews \& Hutchings 1980, Brown 1992) and macroalgal species that generate detritus (Bolton et al. 2004) along the southern African coastline, implying that intertidal filter feeders in particular may experience differences not only in the quantity, but also the quality of food available to them. It has long been suggested that both estuarine and marine bivalves assimilate most of their dietary carbon through the uptake of phytoplankton (Widdows et al. 1979, Asmus \& Asmus 1991, Dame \& Prins 1998). Recently, however, with the introduction of stable isotope analysis, it has been possible to trace the flow of organic matter directly from source to consumer (Kaehler et al. 2000). The application of this technique has led to the suggestion that uptake of macroalgal carbon by filter feeders, through detrital food webs in benthic and pelagic communities has been underestimated (e.g. Dunton \& Schell 1987, Duggins et al. 1989, Bustamante \& Branch 1996). As a result, the importance of phytoplankton versus macroalgal detritus as food sources for intertidal communities is increasingly being called into question (Stuart et al. 1982, Bustamante \& Branch 1996, Vizzini et al. 2002).

Stable isotope analysis has proven to be a powerful tool for resolving trophic relationships and several studies have shown the importance of biogeography in relation to isotope signatures. Rau et al. (1982) reported changes in plankton $\delta^{13} \mathrm{C}$ values with latitude and Burton \& Koch (1999) presented evidence that pinnipeds demonstrate latitudinal differences in collagen carbon values, indicating variation in lower trophic levels. Similarly, in other marine mammals, carbon isotope signatures vary with geographical position (Hobson et al. 2002), allowing the identification of movement over large latitudinal ranges, by identifying different sources of primary production (Burton et al. 2001). Despite these studies, there has been limited research on biogeographic variation in isotopic composition of marine consumers and their food, especially within intertidal benthic communities.

The aims of this study were to investigate the effects of biogeographic and temporal variation in coastal hydrography on food resources of intertidal mussels along the southern African coastline by means of stable isotope analysis, examining the $\delta^{13} \mathrm{C}$ and $\delta^{15} \mathrm{~N}$ ratios from suspended particulate matter (SPM), mussels and macroalgae. These were analyzed to establish (1) if nearshoreoffshore isotopic gradients exist, and whether they can be linked to isotopi- cally distinct sources of production, (2) if existing nearshore-offshore gradients and isotopic signatures of intertidal consumers and producers vary biogeographically and/or temporally, and (3) the relative importance of pelagic primary production (i.e. phytoplankton) versus coastal detritus in the diet of intertidal mussels.

\section{MATERIALS AND METHODS}

Sample collection. SPM samples were obtained from 5-liter surface water samples taken at 12 rocky shore sites along the southern African coastline, from Walvis Bay in Namibia to Sodwana Bay, near the Mozambique border (Fig. 1), in austral summers January to February 2002 and November to December 2003, and austral winter June to July 2004. At each site, duplicate water samples were collected along a transect running perpendicular to the coast at distances of $0,0.25,0.5,1,2,4$ and $10 \mathrm{~km}$. In 2002, samples were collected at only 5 sites, the Port Nolloth transect was collected once in the June to July 2004 period and the Walvis Bay transect was collected once in the November to December 2003 period. Due to logistic constraints, only 2 of the samples collected were between 0 and $10 \mathrm{~km}$ at Walvis Bay. Five mussels (either Perna perna or Mytilus galloprovincialis depending on the site) and samples of the most abundant macroalgae species ( $\mathrm{n}=2$ to 8 depending on availability) were collected at each of the SPM transect sites and at 2 additional sites: Zinkwaze Beach and St. Helena Bay (Fig. 1).

Because different mussel species occur around the coast (Mytilus galloprovincialis is found on the west coast and Perna perna on the east coast), 15 indi-

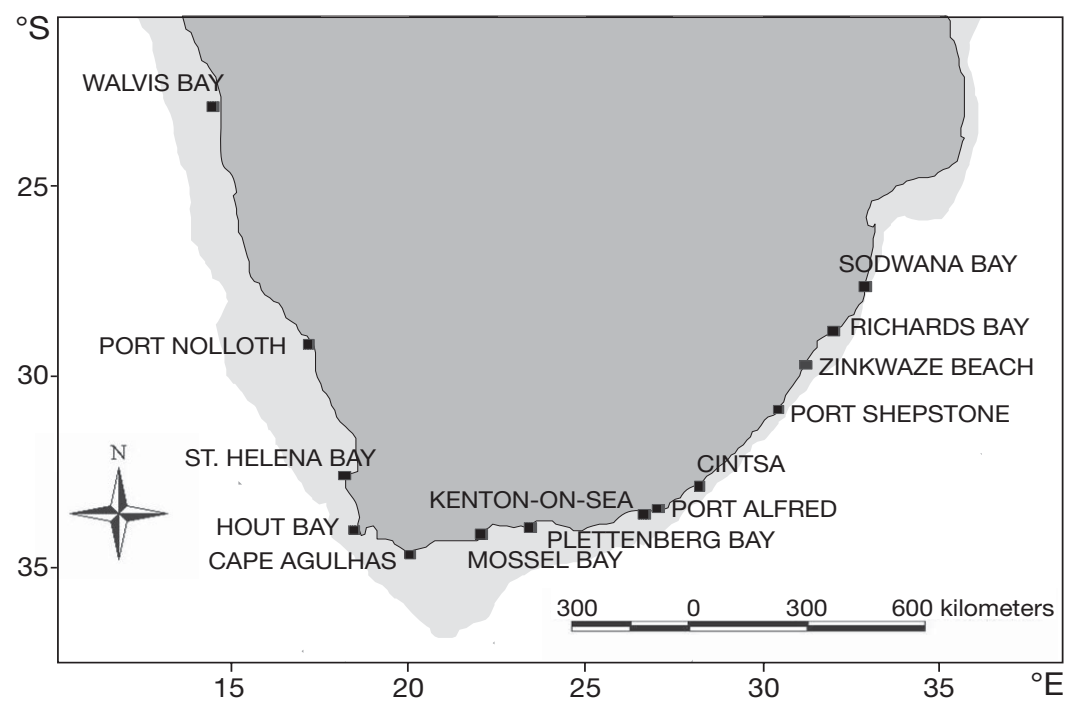

Fig. 1. Map of southern Africa, showing sample sites along the coastline. Light grey shaded area: continental shelf $(\leq 500 \mathrm{~m}$ depth) 
viduals of each species were collected from the same shore and intertidal zone, near Port Alfred, where the 2 co-occur. These animals were analyzed to test for interspecific differences in $\delta^{13} \mathrm{C}$ and $\delta^{15} \mathrm{~N}$ signatures. $t$-tests showed no significant difference between mean isotopic carbon $(p>0.05)$ or nitrogen $(p>0.05)$ values between species (power of test was 0.99).

Sample preparation. Water samples were filtered through pre-combusted $\left(500^{\circ} \mathrm{C}, 6 \mathrm{~h}\right) \mathrm{GF} / \mathrm{F}$ (Whatman ${ }^{\circledR}$ ) filters $(0.45 \mu \mathrm{m}$ pore size), using a vacuum pump ( $\leq 4 \mathrm{~cm}$ $\mathrm{Hg}$ ) and then oven dried at $60^{\circ} \mathrm{C}$ for $24 \mathrm{~h}$. Zooplankton and other large particles were manually removed under a dissecting microscope (16×). Mussel adductor muscle tissue was removed, rinsed in distilled water $\left(\mathrm{dH}_{2} \mathrm{O}\right)$ and oven dried $\left(60^{\circ} \mathrm{C}, 48 \mathrm{~h}\right)$. Adductor muscle tissue was used in this study, as muscle tissue has low turnover rates (Gorokhova \& Hansson 1999) and is therefore more representative of a time-integrated diet. All macroalgae were rinsed in $\mathrm{dH}_{2} \mathrm{O}$, visible epiphytes were removed and algae were also oven dried $\left(60^{\circ} \mathrm{C}, 48 \mathrm{~h}\right)$. Two replicates of each macroalgal sample were prepared for analysis.

Isotopic analysis. $\delta^{13} \mathrm{C}$ and $\delta^{15} \mathrm{~N}$ signatures of all samples were determined using a continuous flow Isotope Ratio Mass Spectrometer (IRMS), after sample combustion in on-line Carlo-Erba preparation units calibrated relative to the standards of air and the International Atomic Energy reference material of PDB (PeeDee Belemnite). Beet sugar, air and gelatine (Merck) were used as standards, calibrated against multiple International Atomic Energy reference materials. Results are expressed in standard delta notation, $\delta \mathrm{X}=\left(\left[\mathrm{R}_{\text {sample }}\right)\right.$ $\left.\left.R_{\text {standard }}\right]-1\right) \times 1000$, where $X$ is the element in question and $\mathrm{R}$ is the ratio of heavy to light isotope. Precision of replicate determinations was $\pm 0.05 \%$ for both carbon and nitrogen.

Data analysis. $\delta^{13} \mathrm{C}$ and $\delta^{15} \mathrm{~N}$ mussel signatures were analyzed using a k-means cluster analysis based on Euclidian distances, validated using a discriminant function analysis (DFA). All analyses were performed using Statistica v7 (StatSoft 2004). Carbon and nitrogen contour graphs were created using Ocean Data View 3 (Schlitzer; available at www.awi-bremerhaven. de/GEO/ODV). A linear 2-source mixing model (Bustamante \& Branch 1996) was used to determine the percentage of organic carbon and nitrogen contributed to mussel diet by nearshore SPM:

$$
\begin{gathered}
\text { \% Isotope }=\left[\left(d_{\text {mussel }}-d_{\text {offshore }}-I\right) /\right. \\
\left.\left(d_{\text {nearshore }}-d_{\text {offshore }}\right)\right] \times 100
\end{gathered}
$$

where $I$ is the average fractionation of $\delta^{13} \mathrm{C}$ or $\delta^{15} \mathrm{~N}$ per trophic level and $d$ is the isotopic ratio of the sample. In this study the average fractionation values of $1 \%$ for $\delta^{13} \mathrm{C}$ (DeNiro \& Epstein 1978, Fry \& Sherr 1984) and 3 to $4 \%$ for $\delta^{15} \mathrm{~N}$ (Fry \& Sherr 1984, Minagawa \& Wada 1984) were used.

\section{RESULTS}

\section{Suspended particulate matter}

SPM showed highly enriched $\delta^{15} \mathrm{~N}$ ratios $(>10.0 \%$ ) between 0 and $4 \mathrm{~km}$ at Port Alfred and Mossel Bay in 2003, but otherwise lacked clear geographic, spatial or

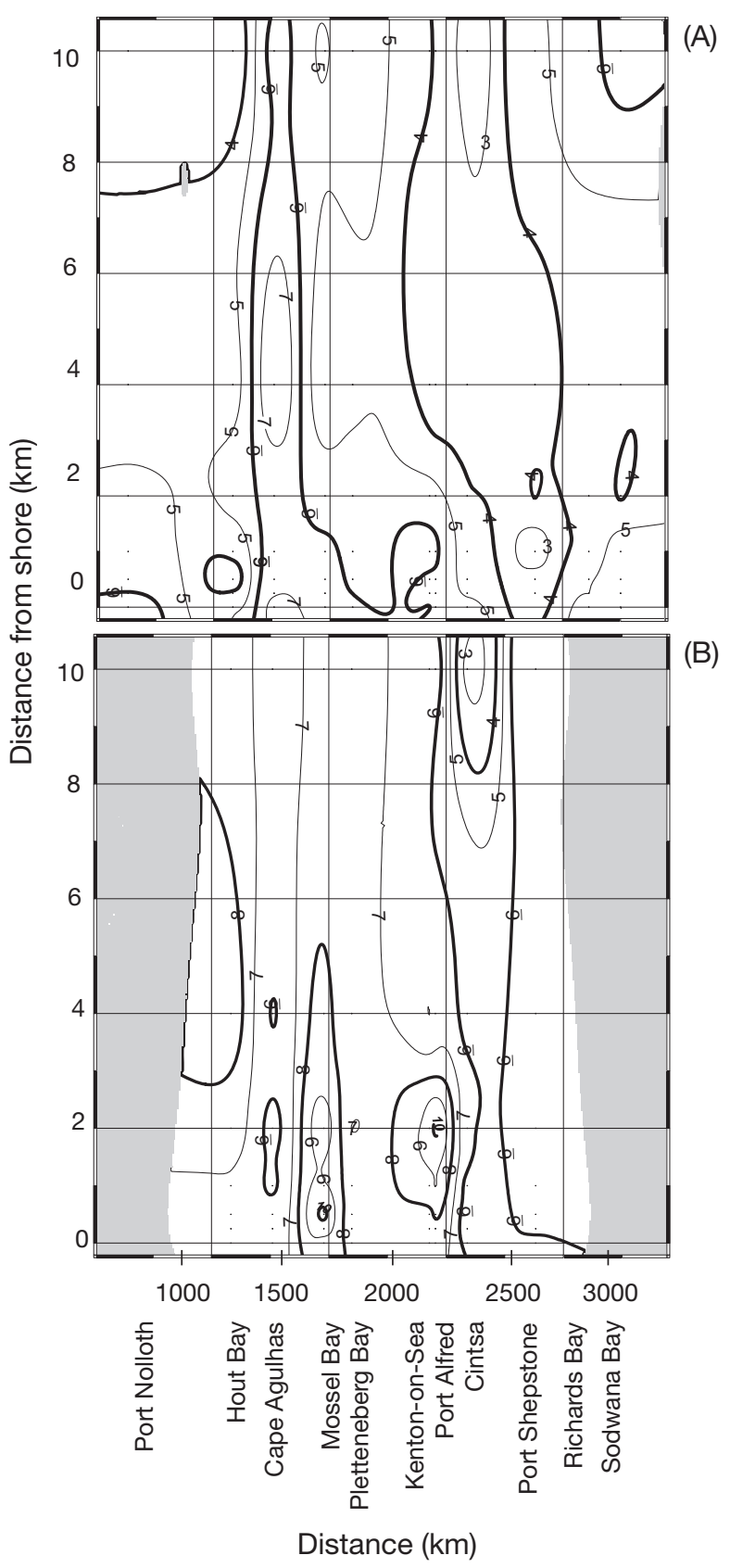

Fig. 2. Contour graphs of $\delta^{15} \mathrm{~N}$ signatures from suspended particulate matter (SPM) transects in (A) winter 2004 and (B) summer 2003 (graph excludes Walvis Bay as only 2 points in the transect fell between 0 and $10 \mathrm{~km}$ ). Distance is in $\mathrm{km}$ along the coastline from Walvis Bay, Namibia. Shaded areas: no data available 
temporal trends (Fig. 2A,B). In contrast, $\delta^{13} \mathrm{C}$ signatures exhibited spatial trends of depletion from nearshore to offshore water along the entire coastline (Walvis Bay is excluded as only 2 samples fell between the 0 and $10 \mathrm{~km}$ range). Clear depletion patterns were displayed at 5 sites in all years (Port Shepstone, Kenton-on-Sea, Mossel Bay, Cape Agulhas and Port Nolloth; Fig. 3A [not all sites included]), 3 sites showed patterns that were less clear but conformed to the general depletion trend in at least 1 of 3 yr (Richards Bay, Plettenberg Bay and Hout Bay; Fig. 3B [not all sites included]) and 3 sites demonstrated enrichments on some occasions between 4 and $10 \mathrm{~km}$ offshore (Sodwana Bay, Cintsa and Port Alfred; Fig. 4). Values for nearshore (intertidal, $0 \mathrm{~km}$ ) water ranged from highly enriched carbon values of $-6.99 \pm 0.81 \%$ (Cape Agulhas) to much more depleted values of $-19.4 \pm 0.01 \%$ (Sodwana Bay), with an average of $-15.4 \pm 3.06 \%$, while offshore $(10 \mathrm{~km})$ waters displayed less variation, ranging between $-16.98 \pm 0.25 \%$ (Hout Bay) and $-23.58 \pm 0.09 \%$ (Port Nolloth), with an average of $-20.36 \pm 1.84 \%$. $\delta^{13} \mathrm{C}$ depletion curves were more enriched at 5 sites (Richards Bay, Cintsa, Port Alfred, Plettenberg Bay and Hout Bay) in 2003 than in other years, ranging from a 2 to $4 \%$ increase depending on site and sample, suggesting overall enrichment in austral summer but with no obvious geographic trends.

(A)
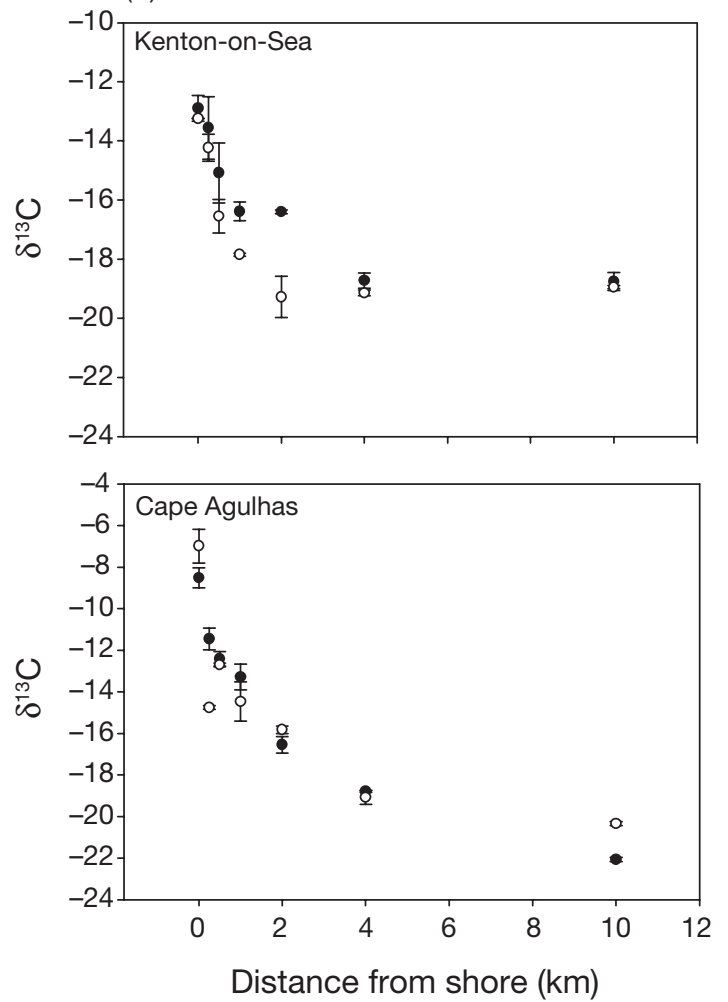

Nearshore SPM demonstrated an overall geographic enrichment in $\delta^{13} \mathrm{C}$ from the east coast (Sodwana Bay) with a mean $\delta^{13} \mathrm{C}$ of $-18.7 \pm 0.67 \%$, to the south coast (Cape Agulhas) with a mean $\delta^{13} \mathrm{C}$ of $-7.8 \pm 1.08 \%$, while offshore water remained relatively constant at an average of $-20.36 \pm 1.84 \%$ (Fig. 5).

Along the coastline, 6 sites (Sodwana Bay, Richards Bay, Cintsa, Plettenberg Bay, Mossel Bay, Port Nolloth) showed nearshore SPM $\delta^{13} \mathrm{C}$ values lower than the midpoint between nearshore and offshore signatures $(<-17.88 \%)$. The remaining 5 sites showed nearshore SPM values higher than the midpoint (>-17.88\%o) and these pockets of enriched nearshore SPM extended out to a maximum of $2 \mathrm{~km}$ from the shoreline (Fig. 6A,B).

\section{Macroalgae}

Macroalgal signatures showed no consistent geographic or temporal trends in either $\delta^{13} \mathrm{C}$ or $\delta^{15} \mathrm{~N}$, with erratic enrichments and depletions in consecutive years, and most macroalgae showed large ranges in both carbon and nitrogen. Both Ulva sp. and Gelidium pristoides, for example, demonstrated large scale differences along the coastline ranging between $\delta^{13} \mathrm{C}$ values of -10.89 to $-17.83 \%$ and -11.49 to $-15.66 \%$ and $\delta^{15} \mathrm{~N}$ values of 4.39 to $7.20 \%$ and 5.85 to $7.69 \%$, respec-

(B)
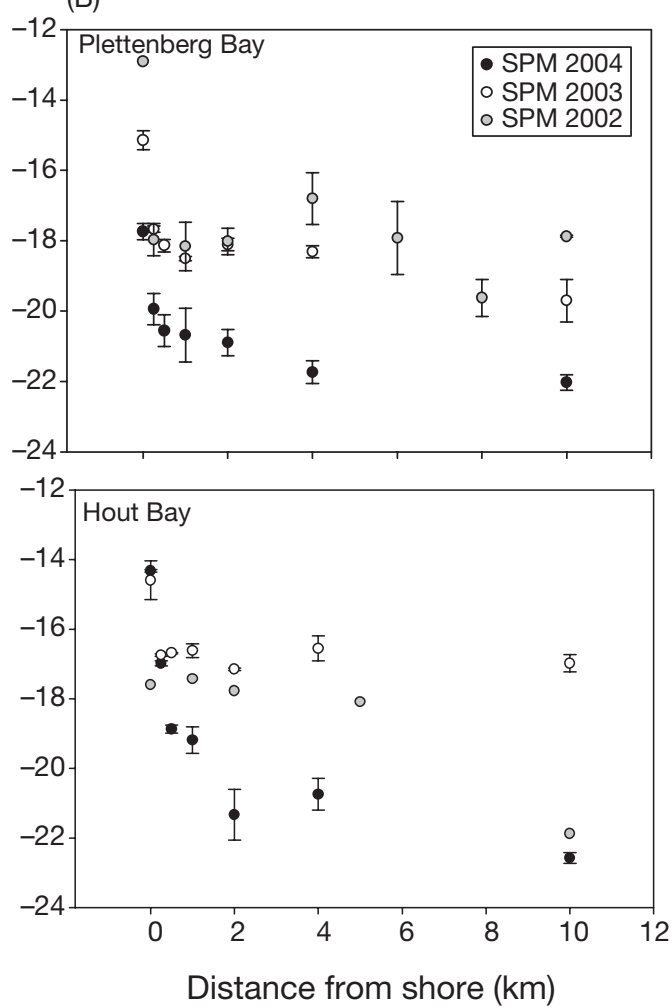

Fig. 3. (A) Examples of nearshore-offshore $\delta^{13} \mathrm{C}$ gradients from sample sites along the coastline showing clear depletion trends; (B) as (A) but showing weaker depletion trends. Values are mean $\pm \mathrm{SD}$ 

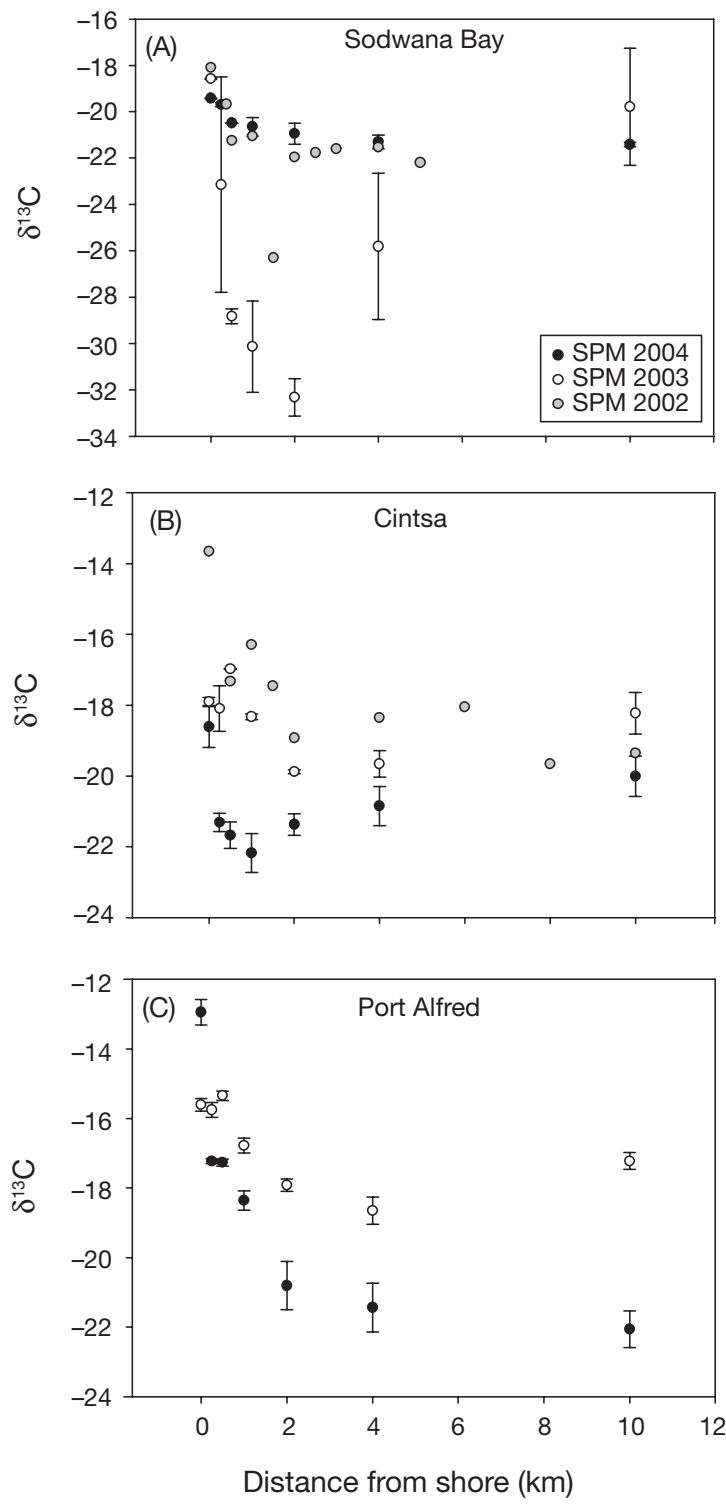

Fig. 4. Deviations from the overall nearshore to offshore $\delta^{13} \mathrm{C}$ trends of suspended particulate matter (SPM). Values are means $\pm \mathrm{SD}$

tively. Consequently, macroalgal isotopic ratios could not be related to either mussel diet or nearshore SPM and the data are therefore not presented.

\section{Mussels}

Although many sites showed considerable variation in $\delta^{13} \mathrm{C}$ values of mussel tissue between sampling occasions, there were no consistent seasonal or interannual trends among sites. There were, however, distinct geographic patterns, allowing the k-means cluster analysis to classify the mussels into 4 isotopic groups that represent animals collected from the east, southeast, south-west and west coasts (Fig. 7). Subsequent DFA showed that these clusters could be identified by their signatures alone with 97 to $98 \%$ accuracy. The east coast group (group A) was characterized by low $\delta^{13} \mathrm{C}$ and $\delta^{15} \mathrm{~N}$ values $\left(\delta^{13} \mathrm{C}:-17.63\right.$ to $-16.56 \%$; $\delta^{15} \mathrm{~N}$ : 6.31 to $7.78 \%$ ), the south-east coast group (group B) by intermediate $\delta^{13} \mathrm{C}$ and $\delta^{15} \mathrm{~N}$ values $\left(\delta^{13} \mathrm{C}\right.$ : -16.19 to $-15.37 \%$; $\delta^{15} \mathrm{~N}$ : 6.73 to $8.17 \%$ ) and the south-west (group C) and west coasts (group D) $\left(\delta^{13} \mathrm{C}:-15.85\right.$ to $-14.45 \%$; $\delta^{15} \mathrm{~N}: 8.35$ to 9.033 and $\delta^{13} \mathrm{C}:-17.50$ to $-16.78 \%$; $\delta^{15} \mathrm{~N}$ : 8.85 to $9.6 \%$, respectively) by their high $\delta^{15} \mathrm{~N}$ values (Fig. 7). Two exceptions were Site 11 (S11: Hout Bay), which fell into the south-east grouping in all 3 years, and Site 5 (S5: Cintsa) which was grouped with group A in 2002 and 2003, but with group B during 2004. From the east to the south coast, both mussel carbon $\left(\mathrm{r}^{2}=0.71, \mathrm{p}<0.01\right)$ and nitrogen $\left(\mathrm{r}^{2}=0.69, \mathrm{p}<0.01\right)$ ratios demonstrated enrichment (excluding all sites west of Cape Agulhas) (Fig. 8). Although it was not possible to associate near-offshore carbon values with distinct sources of production, links were found between isotopic values of nearshore water and macroalgae, and offshore water and phytoplankton. The linear mixing model revealed that mussels demonstrated more than a $50 \%$ dependence on nearshore water for their organic carbon and nitrogen, at 8 and 7 out of 11 sites respectively. In both cases, 2 locations (Cintsa and Hout Bay) showed strong temporal variation (Fig. 9).

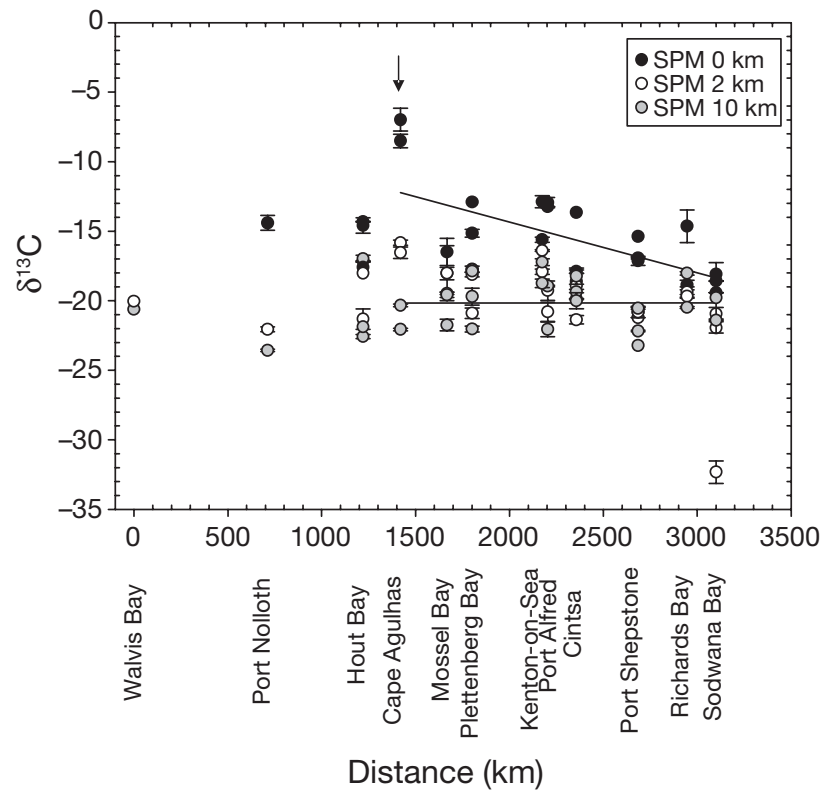

Fig. 5. $\delta^{13} \mathrm{C}$ of suspended particulate matter (SPM) along the coastline. Regression excludes values to the west of Cape Agulhas, i.e. to the left of the arrow. Distance is in $\mathrm{km}$ along the coastline from Walvis Bay, Namibia. Values are means \pm SD and are presented separately for each yr 


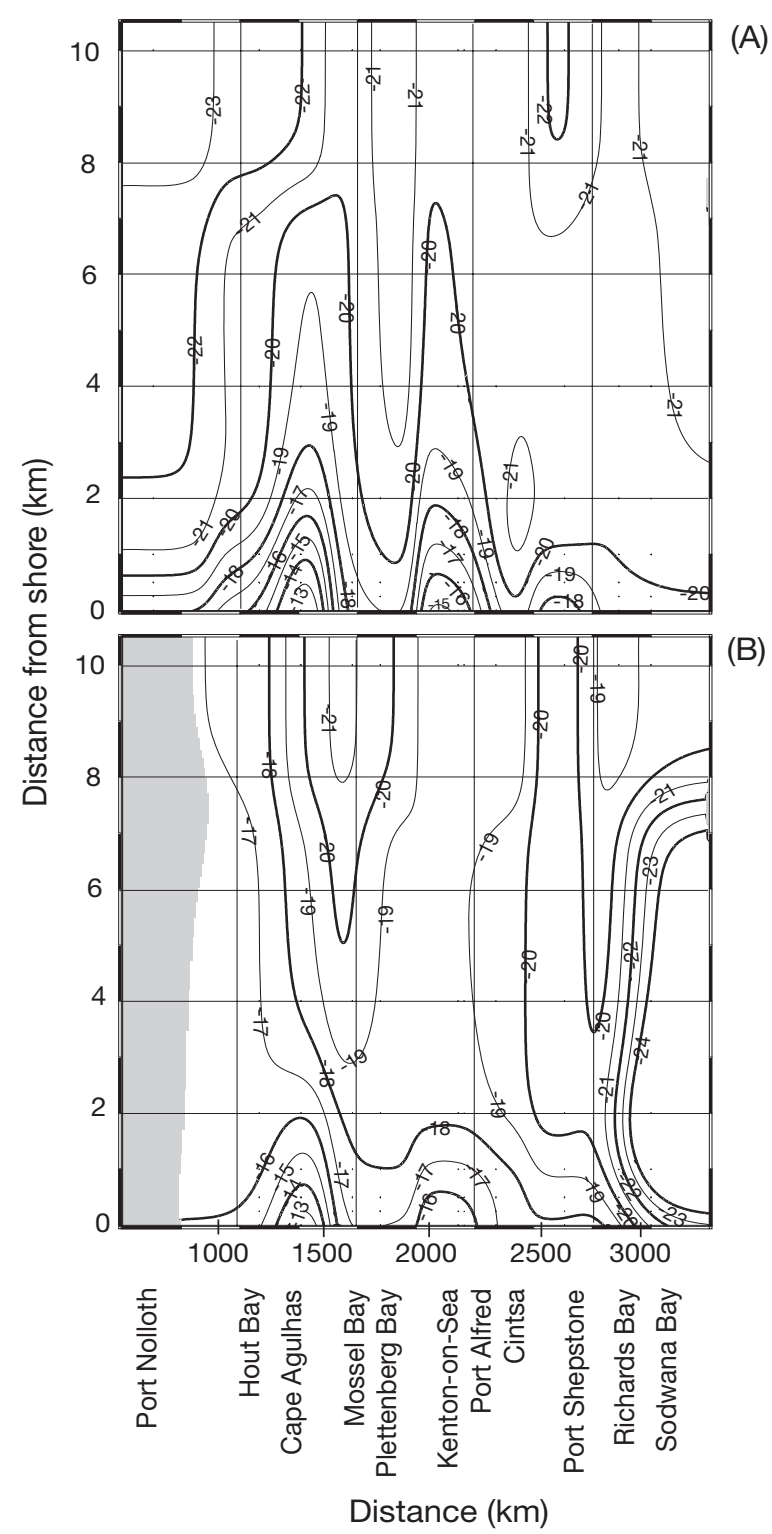

Fig. 6. Contour graphs of $\delta^{13} \mathrm{C}$ signatures from suspended particulate matter (SPM) transects in (A) winter 2004 and (B) summer 2003 (graph excludes Walvis Bay as only 2 points in the transect fell between 0 and $10 \mathrm{~km}$ ). Distance is in $\mathrm{km}$ along the coastline from Walvis Bay, Namibia. Shaded areas: no data available

\section{DISCUSSION}

\section{Spatial and biogeographic gradients}

Spatial patterns in carbon signatures reflect patterns in the distribution or signatures of primary producers, which in turn are likely to reflect environmental gradients, and recent investigations have also shown variation in carbon isotopes on several physical scales. These include spatial patterns within estuarine ecosys-

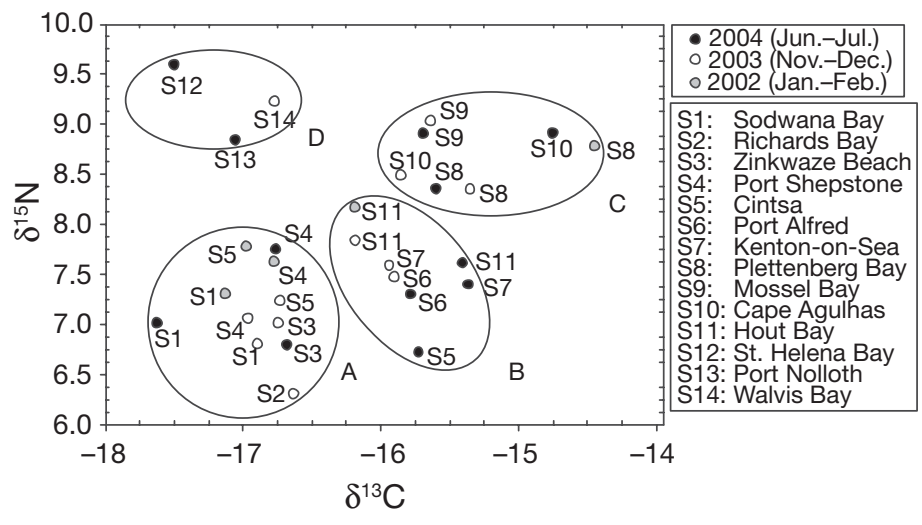

Fig. 7. $\delta^{13} \mathrm{C}$ and $\delta^{15} \mathrm{~N}$ signatures of intertidal mussels. Groupings according to k-means cluster analysis: (A) east coast,

(B) south-east coast, (C) south-west coast, (D) west coast

tems (Deegan \& Garritt 1997), which exhibit very strong environmental gradients, and global latitudinal trends in pinnipeds (Burton \& Koch 1999, Hobson et al. 2002) and squid (Takai et al. 2000). In the present study we explored trends in carbon signature along 2 gradients. The first was a nearshore-offshore gradient likely to reflect a gradient of decreasing macrophyte influence; the second was a biogeographic gradient that reflects the influence of 2 very different oceanographic regimes, rather than a latitudinal effect.

\section{Nearshore-offshore gradients}

With few exceptions, $\delta^{13} \mathrm{C}$ signatures of SPM became depleted with distance from shore. This trend of depletion suggests a shift from a nearshore carbon supply to one more representative of a pelagic carbon source. Although it was not possible to link these $\delta^{13} \mathrm{C}$ values directly to distinct sources of production, the nearshore $(0 \mathrm{~km})$ signatures, with an average of $15.4 \%$, fell into the range of carbon values previously reported for macroalgae (Smith \& Epstein 1971, Bustamante \& Branch 1996), and are presumably representative of a nearshore primary production signature. Nearshore water consists of a mixture of phytoplankton, organic and inorganic debris (Stuart 1982, Bustamante \& Branch 1996) and is likely dominated by macroalgal detritus (Mann 1988, Duggins et al. 1989, Bustamante \& Branch 1996, Vizzini et al. 2002). Although nearshore carbon values fell within the range of algal signatures found along the coast in this study, the two could not be directly related to one another. In retrospect, this is not surprising, as SPM samples are unlikely to have had the same algal composition as the seaweeds subsampled from the intertidal zone. Offshore $(10 \mathrm{~km})$ signatures (average: $-20.36 \%$ ) fell into the $\delta^{13} \mathrm{C}$ range previously reported for oceanic phyto- 

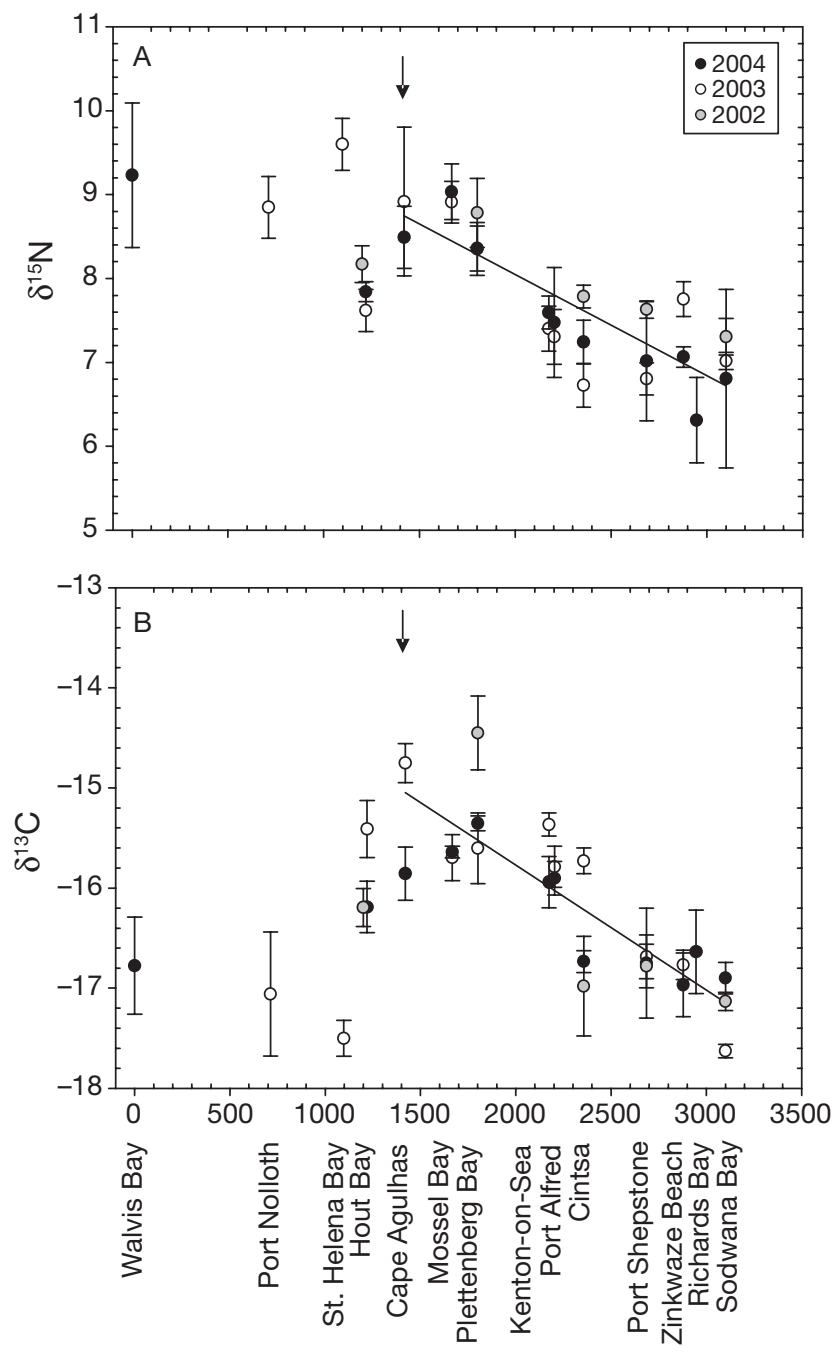

Distance from Walvis Bay, Namibia $(\mathrm{km})$

Fig. 8. (A) $\delta^{15} \mathrm{~N}$ geographic enrichment of intertidal mussels, $\mathrm{r}^{2}=$ $0.69, \mathrm{p}<0.01, y=10.4594-0.0012 x_{i}$ (B) $\delta^{13} \mathrm{C}$ geographic enrichment of intertidal mussels, $\mathrm{r}^{2}=0.71, \mathrm{p}<0.01, y=-13.2726-$ $0.0012 x$. Regression excludes values to the west of Cape Agulhas, i.e. to the left of the arrows. Values are means \pm SD

plankton (Rau et al. 1982, Fry \& Sherr 1984) and appear to be typical of pelagic production, as carbon signatures at Kenton-on-Sea remain in the range of -20.00 to $-21.5 \%$ as far as $50 \mathrm{~km}$ offshore (Kaehler unpubl.).

Although nearshore-offshore depletion was ubiquitous around the coast, the slopes of the curves varied among sites and years, suggesting not only geographic but also temporal effects on offshore depletion. Previous studies on phytoplankton (a main component of offshore SPM) show that photoperiod, temperature, light intensity and nutrient supply all serve to increase growth rates (Rau et al. 1996, Burkhardt et al. 1999), and hence the $\delta^{13} \mathrm{C}$ signature of SPM. Studies investi-
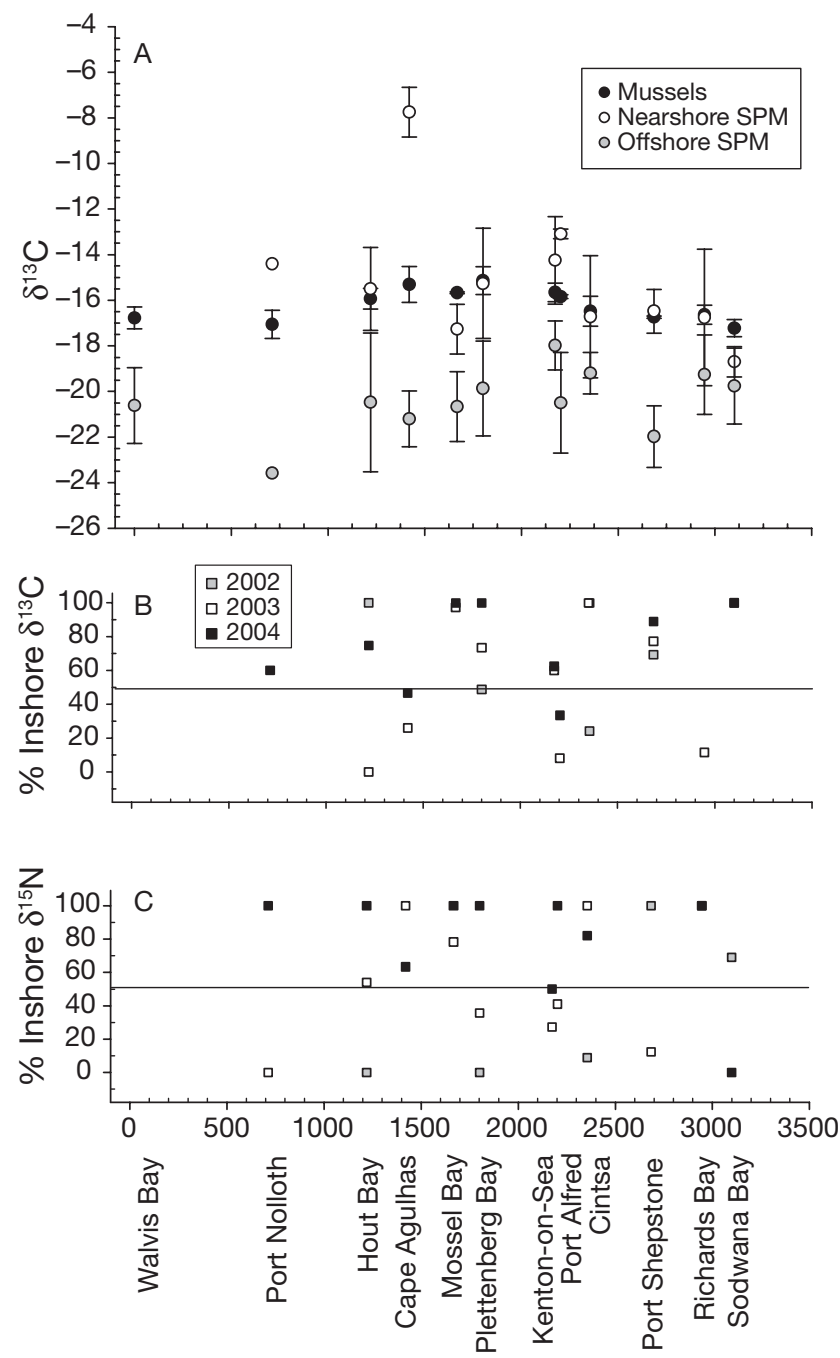

Distance from Walvis Bay, Namibia $(\mathrm{km})$

Fig. 9. (A) Isotopic relationships between mussels, nearshore and offshore suspended particulate matter (SPM) for 2002 to 2004; (B) percentage $\delta^{13} \mathrm{C}$ contribution of nearshore SPM to mussel diet; (C) as (B) for $\delta^{15} \mathrm{~N}$

gating phytoplankton biomass in the southwest Indian Ocean using measurements of chlorophyll a have shown increased primary production and $\delta^{13} \mathrm{C}$ of SPM in austral winter (Falkowski et al. 1998, Machu et al. 2005). Our transects started much farther inshore than these studies, overlapping marginally offshore, but showed austral summer (January to February 2002 and November to December 2003) depletion curves that were either more enriched, or in 4 cases, similar to carbon values found in winter (June to July 2004), suggesting a general tendency for SPM to be more enriched in austral summer than in winter. Unless seasonal differences exist in phytoplankton species composition of SPM, it is likely that the observed $\delta^{13} \mathrm{C}$ 
enrichment during austral summer was due to local effects, rather than seasonal patterns in oceanic carbon. Variation in position and meandering of the Agulhas current (Goschen \& Schumann 1990), extent of mixing between near and offshore waters and changes in local autochthonous or allochthonous inputs on a regional scale may have a large effect on SPM composition (Megens et al. 2001), changing $\delta^{13} \mathrm{C}$ signatures on a daily basis.

$\delta^{13} \mathrm{C}$ SPM inflection points, where nearshore signatures changed to more pelagic ones, generally occurred between $500 \mathrm{~m}$ and $1 \mathrm{~km}$ from the shore, but occurred further offshore at some sites (e.g. Hout Bay, Cape Agulhas, Kenton-on-Sea, Port Alfred and Port Shepstone; Fig. 6A,B). In both 2003 and 2004 Hout Bay/Cape Agulhas and Kenton-on-Sea/Port Alfred showed pockets of enriched nearshore SPM extending out to a maximum of $2 \mathrm{~km}$ from the shoreline and signatures only became typically pelagic $(-20.0$ to $-21.5 \%)$ at $10 \mathrm{~km}$. Port Shepstone showed a similar peak in $\delta^{13} \mathrm{C}$, but on a much smaller scale. These data indicate that, while at 5 sites along the coastline, water with a pelagic signature may often come close inshore to introduce offshore organic carbon to the intertidal zone, the reverse may also occur, with nearshore water extending to fairly significant distances offshore. For example, Koop et al. (1982), working at Oudekraal Bay, showed that mannitol-fermenting bacteria derived from kelp beds within 100 to $200 \mathrm{~m}$ of the shore could be found as far as $10 \mathrm{~km}$ offshore. This sitespecific offshore extension of enriched $\delta^{13} \mathrm{C}$ values may represent local differences in coastal hydrography, dynamic upwelling (Lutjeharms et al. 2000), current position and limited forcing of nearshore water out to sea due to wind pressures and the circulation patterns of the Agulhas current (Goschen \& Schumann 1990, Boyd \& Shillington 1994).

\section{Biogeographic gradients}

$\delta^{13} \mathrm{C}$ values for SPM of nearshore water showed an overall geographic enrichment from an average of $-18.7 \pm 0.67 \%$ on the east coast to $-7.8 \pm 1.08 \%$ on the south coast, while offshore water remained relatively constant at an average of $-20.36 \pm 1.84 \%$. This trend of east-south enrichment of nearshore carbon applied only to sites within the Agulhas system and excluded all sites to the west of Cape Agulhas. The remaining sites showed lower carbon values both nearshore and offshore, most likely reflecting the influence of the Benguela current and the geographic shift to a colder water and more nutrient-rich ecosystem (Emanuel et al. 1992). Nearshore carbon enrichment from east to south reflects changes in coastal hydrography. Where the continental shelf is narrow (east coast), the Agul- has current comes close inshore (Goschen \& Schumann 1990, 1994), resulting in nearshore water being well mixed with offshore water. Further south, the shelf begins to widen and the Agulhas moves offshore (Roberts 2005), weakening the mixing effect and ensuring larger carbon differences between nearshore and offshore water. The biogeographic consistency in offshore $\delta^{13} \mathrm{C}$ indicates well mixed pelagic waters $10 \mathrm{~km}$ from shore along the entire coast. Overall $\delta^{13} \mathrm{C}$ signatures seem to reflect the existence of known hydrographic features along the coast (i.e. upwelling regions, current meanders, shelf width and shelf abnormalities such as canyons) and should therefore be considered for future use in studying water mixing and coastal hydrography. Nevertheless, instantaneous SPM samples give only a snapshot in time, and may not be the best measure for determining timeintegrated carbon source availability and composition.

\section{Mussels and diet}

The lack of clear temporal variation in the adductor tissue, of both $\delta^{13} \mathrm{C}$ and $\delta^{15} \mathrm{~N}$ values suggests that either adductor tissue has a slow turnover rate or that at each site, the average mussel diet is relatively constant year round. We are not aware of any direct measurements of turnover rates in adductor muscle tissue, and recognize that individual tissues contribute differentially to whole body protein turnover rates. However, Hawkins (1985) found that laboratory-measured whole body protein turnover rates in Mytilus edulis varied with absorption rates, reaching maximum values of 0.29 to $0.4 \% \mathrm{~d}^{-1}$. This suggests $100 \%$ turnover rates of the order of 244 to $350 \mathrm{~d}$ or approximately $8 \mathrm{mo}$ to $1 \mathrm{yr}$ and may explain the lack of temporal variation seen in the mussel tissue. Using carbon and nitrogen signatures, mussels around the southern African shoreline could be divided into 4 groups, with a clear geographic pattern. The east coast group (A) encompassed Sodwana Bay to Cintsa; the south-east coast group (B) encompassed Port Alfred and Kenton-on-Sea; the south-west coast group (C) encompassed Plettenberg Bay to Cape Agulhas; and the west coast group (D) encompassed St. Helena Bay to Walvis Bay, Namibia. Two sites did not conform to this biogeographic pattern, the first deviation was Site 11 (S11: Hout Bay), which lies on the west coast, near the Cape of Good Hope, but fell into the south-east coast group (group B) in all years, with its $\delta^{15} \mathrm{~N}$ values lying at the group boundary in 2 out of 3 years. The reason for the inclusion of Hout Bay in group B is unknown. The second exception was Site 5 (S5: Cintsa) which showed strong $\delta^{13} \mathrm{C}$ enrichment during austral winter, indicating a change in diet in June-July 2004. Cintsa was grouped with its geo- 
graphic neighbours in group B in the winter sample (2004), but with its other neighbour, the more depleted group A, in both summer samples (2002 and 2003). This suggests that either Cintsa lies close to the boundary between the east and south coast carbon sources, or that carbon sources available to mussels in group A are more thoroughly mixed than those from group B.

Among sites, $\delta^{15} \mathrm{~N}$ exhibited geographic enrichment with a clear gradient from east to south-west, excluding all sites to the west of Cape Agulhas. This reflects the isotopic gradient from oligotrophic to eutrophic conditions, described by Saino \& Hattori (1980) and Minagawa \& Wada (1984). These isotopic differences are likely due to a reliance on recycled nitrogen (especially ammonia) in oligotrophic waters, which is depleted in $\delta^{15} \mathrm{~N}$ relative to the upwelled nitrate used in eutrophic systems (Miyake \& Wada 1967). Mussel tissue exhibited geographic $\delta^{13} \mathrm{C}$ enrichment from the east to the south-west coast, again excluding all locations to the west of Cape Agulhas. The west coast sites showed significant carbon depletions, mirroring the trend seen in nearshore SPM. Although a consistent fractionation value of 1.0\% (DeNiro \& Epstein 1978, Fry \& Sherr 1984) was not evident between offshore or nearshore SPM and mussel tissue, the latter two show similar patterns in $\delta^{13} \mathrm{C}$ enrichment from east to southwest coast, indicating a close overall link between them. It is unrealistic to expect time-integrated mussel tissue to reflect the instantaneous nature of the SPM sample, which is subject to constant interplay between nearshore and offshore water, varying temporally on a local scale (Goschen \& Schumann 1990), and this difference in time-scale integration may mask the relationship between the two.

Mussels are unlikely to depend on a single food source, relying instead on the changing sources of carbon available in the water column, and filtering selectively (Bougrier et al. 1997, Ward et al. 1998). We hypothesized that mussels eating macroalgal detritus would reflect $\delta^{13} \mathrm{C}$ values of the nearshore SPM, while those eating phytoplankton would have similar carbon values to offshore SPM. At 7 out of 10 sites (Walvis Bay lacked nearshore SPM values) mussel tissue showed $\delta^{13} \mathrm{C}$ values similar to, or just above those of nearshore SPM. This indicates that mussels at these sites either fed non-selectively, and so reflected available carbon in nearshore SPM, or selected for macroalgal detritus. At the remaining 3 sites, mussel tissue had intermediate $\delta^{13} \mathrm{C}$ values, falling between those for nearshore and offshore SPM (Fig. 9), suggesting a possible preferential selection of phytoplankton (Bougrier et al. 1997, Rouillon \& Navarro 2003) from the nearshore SPM, but more likely reflecting local differences in nearshore SPM composition and available organic carbon.
The application of a linear mixing model allowed us to determine the percentage contribution of nearshore and offshore SPM to the overall $\delta^{13} \mathrm{C}$ and $\delta^{15} \mathrm{~N}$ signatures for each mussel sample, investigating the dietary importance of nearshore versus pelagic primary production. Surprisingly, nearshore SPM accounted for over $50 \%$ of both carbon and nitrogen incorporated by mussels at all but 3 sites (for carbon) and 4 sites (for nitrogen) along the coastline ( 2 sites demonstrated temporal variation; Fig. 9), although there was otherwise little congruence between the two. A number of studies of variability in the $\delta^{13} \mathrm{C}$ signatures of marine phytoplankton ascribe lower values to colder water temperatures and increased solubility of $\mathrm{CO}_{2}$ (Arthur et al. 1985, Fry 1996), and this is supported by evidence of depleted carbon values in Antarctic plankton relative to plankton from equatorial waters (Rau et al. 1989). In the present study however, although we have no information on the composition of the phytoplankton in nearshore and offshore SPM, it is unlikely that such an effect would be caused by a steep $\mathrm{CO}_{2}$ gradient existing on a scale of $10 \mathrm{~km}$. Therefore, differences in $\delta^{13} \mathrm{C}$ between nearshore and offshore SPM are attributed to different carbon sources in terms of phytoplankton and macroalgae. Consequently, unless nearshore (intertidal, $0 \mathrm{~km}$ ) water contains different phytoplankton communities to water $10 \mathrm{~km}$ offshore, this overall reliance on nearshore primary production suggests that overall, mussels are feeding unselectively, and emphasizes the dietary importance of macroalgal detritus for mussels in the intertidal zone.

It is unrealistic to expect SPM samples to reflect a single macroalgal signature when SPM contains a variable composition of detritus from numerous seaweeds and consequently the links between mussel diet and macroalgae remain unclear. No clear, consistent relationship was obvious between living macroalgae and mussel diet or nearshore SPM. A study exploring the effects of seaweed degradation on isotopic signatures may illuminate the links between living macrophytes, mussel diet and nearshore waters and is currently being investigated (J. M. Hill \& C. D. McQuaid unpubl.).

\section{SUMMARY AND CONCLUSIONS}

Overall $\delta^{13} \mathrm{C}$ depletion trends between nearshore and offshore water were seen along the entire coastline, representing changes from nearshore carbon sources that include a component of macrophyte detritus to offshore pelagic carbon sources. Geographically, nearshore SPM became enriched moving from the east to the south coast, while offshore waters remained relatively constant, and the extent of mixing of the 2 carbon sources and the protrusion of nearshore into 
offshore waters seemed to be closely related to hydrographic features or events along the coastline (i.e. shelf width, pulses, current position and upwelling cells).

Mussel tissue demonstrated geographic variation, particularly in carbon, with differences between the east, south and west coasts. Although it was difficult to relate these trends in $\delta^{13} \mathrm{C}$ values or carbon values of near-offshore SPM with distinct sources of production, the linear mixing model revealed a high carbon and nitrogen dependence on nearshore, rather than offshore, SPM, suggesting that nearshore detritus plays a crucial role in mussel diet. This reliance on nearshore SPM is of further significance if we consider that mussels are a major component of the intertidal biota and are the prey of a wide range of species (Griffiths \& Hokey 1987), playing a major part in retaining nearshore primary production that might otherwise be exported. As the importance of autochthonous primary production to intertidal filter feeders is clarified, it becomes important to focus on regional geographic differences in primary production along the southern African coastline to elucidate changes in SPM composition. Further studies into isotopic signatures of water in the Benguela current system and an investigation into the effect of degradation on macroalgal isotopic ratios may help to unravel the links between SPM and intertidal consumers.

Acknowledgements. Many thanks go to Dr. S. Davis and Dr. R. Kalin at the EERC centre, Queens University Belfast for invaluable assistance, training and guidance as well as the use of their facilities. Thanks also to J. Lanham, University of Cape Town, for his help, and to Dr. B. Currie from the Ministry of Fisheries and Marine Resources, Namibia. Isotope analysis was done both through the EERC centre, Queens University Belfast and the Stable Light Isotope Unit, University of Cape Town.

\section{LITERATURE CITED}

Alexander SE, Roughgarden J (1996) Larval transport and population dynamics of intertidal barnacles: a coupled benthic/oceanographic model. Ecol Monogr 66:259-275

Andrews WRH, Hutchings L (1980) Upwelling in the Southern Benguela Current. Prog Oceanogr 9:1-81

Arthur MA, Dean WE, Claypool GE (1985) Anomalous ${ }^{13} \mathrm{C}$ enrichment in modern marine organic carbon. Nature 315: $216-218$

Asmus R, Asmus H (1991) Mussel beds: limiting or promoting phytoplankton? J Exp Mar Biol Ecol 48:215-232

Blanchette CA, Broitman BR, Gaines SD (2006) Oceanographic forcing of intertidal community structure around Santa Cruz Island, USA. Mar Biol 149:689-701

Bolton JJ, Leliaert F, De Clerck O, Anderson RJ, Stegenga H, Engledow E, Coppejans E (2004) Where is the western limit of the tropical Indian Ocean seaweed flora? An analysis of intertidal seaweed biogeography on the east coast of South Africa. Mar Biol 144:51-59

Bougrier S, Hawkins AJS, Héral M (1997) Preingestive selection of different microalgal mixtures in Crassostrea gigas and Mytilus edulis analysed by flow cytometry. Aquaculture 150:123-134

Boyd AJ, Shillington FA (1994) Physical forcing and circulation patterns on the Agulhas Bank. S Afr J Sci 90: $114-122$

Brown PC (1992) Spatial and seasonal variation in chlorophyll distribution in the upper $30 \mathrm{~m}$ of the photic zone in the southern Benguela/Agulhas ecosystem. S Afr J Mar Sci 12:515-525

Burkhardt S, Riebesell U, Zondervan I (1999) Effects of growth rate, $\mathrm{CO}_{2}$ concentration, and cell size on the stable carbon isotope fractionation in marine phytoplankton. Geochim Cosmochim Acta 63:3729-3741

Burton R, Koch P (1999) Isotopic tracking of foraging and long-distance migration in northeastern Pacific pinnipeds. Oecologia 119:578-585

Burton R, Snodgrass J, Gifford-Gonzalez D, Guilderson T, Brown T, Koch P (2001) Holocene changes in the ecology of northern fur seals: insights from stable isotopes and archaeofauna. Oecologia 128:107-115

Bustamante RH, Branch GM (1996) The dependence of intertidal consumers on kelp-derived organic matter on the west coast of South Africa. J Exp Mar Biol Ecol 196:1-28

Dame R, Prins T (1998) Bivalve carrying capacity in coastal ecosystems. Aquat Ecol 31:409-421

Deegan LA, Garritt RH (1997) Evidence for spatial variability in estuarine food webs. Mar Ecol Prog Ser 147:31-47

DeNiro MJ, Epstein S (1978) Influence of diet on the distribution of carbon isotopes in animals. Geochim Cosmochim Acta 42:495-506

Duggins DO, Simenstad CA, Estes JA (1989) Magnification of secondary production by kelp detritus in coastal marine ecosystems. Science 245:170-173

Dunton KH, Schell DM (1987) Dependence of consumers on macroalgal (Laminaria solidungula) carbon in an arctic kelp community: $\delta^{13} \mathrm{C}$ evidence. Mar Biol 93:615-625

Emanuel BP, Bustamante RH, Branch GH, Odendaal FJ (1992) A zoogeographic and functional approach to the selection of marine reserves on the west coast of South Africa. S Afr J Mar Sci 12:341-354

Falkowski P, Barber R, Smetacek V (1998) Biogeochemical controls and feedbacks on ocean primary production. Science 281:200-206

Fry B (1996) ${ }^{13} \mathrm{C} /{ }^{12} \mathrm{C}$ fractionation by marine diatoms. Mar Ecol Prog Ser 134:283-294

Fry B, Sherr EB (1984) $\delta^{13} \mathrm{C}$ measurements as indicators of carbon flow in marine and freshwater ecosystems. Contrib Mar Sci 27:13-17

Gorokhova E, Hansson S (1999) An experimental study on variations in stable carbon and nitrogen isotope fractionation during growth of Mysis mixta and Neomysis integer. Can J Fish Aquat Sci 56:2203-2210

Goschen WS, Schumann EH (1990) Agulhas current variability and inshore structures off the Cape Province, South Africa. J Geophys Res 95:667-678

Goschen WS, Schumann EH (1994) An Agulhas current intrusion into Algoa Bay during August 1988. S Afr J Mar Sci $14: 47-57$

Griffiths CL, Hockey PAR (1987) A model describing the interactive roles of predation, competition, and tidal elevation in structuring mussel populations. S Afr J Mar Sci 5: $547-556$

Hawkins AJS (1985) Relationships between the synthesis and breakdown of protein, dietary absorption and turnovers of nitrogen and carbon in the blue mussel, Mytilus edulis L. Oecologia 66:42-49

Hobson KA, Fisk A, Karnovsky N, Holst M, Gagnon JM, 
Fortier M (2002) A stable isotope $\left(\delta^{13} \mathrm{C}, \delta^{15} \mathrm{~N}\right)$ model for the North Water food web: implications for evaluating trophodynamics and the flow of energy and contaminants. DeepSea Res II 49:5131-5150

Kaehler S, Pakhomov E, McQuaid C (2000) Trophic structure of the marine food web at the Prince Edward Islands (Southern Ocean) as determined by $\delta^{13} \mathrm{C}$ and $\delta^{15} \mathrm{~N}$ analysis. Mar Ecol Prog Ser 208:13-20

Koop K, Carter RA, Newell RC (1982) Mannitol-fermenting bacteria as evidence for export from kelp beds. Limnol Oceanogr 27:950-954

Lutjeharms JRE, Cooper J, Roberts M (2000) Upwelling at the inshore edge of the Agulhas Current. Contin Shelf Res 20: 737-761

Machu E, Biastoch A, Oschlies A, Kawamiya M, Lutjeharms JRE, Garcon V (2005) Phytoplankton distribution in the Agulhas system from a coupled physical-biological model. Deep-Sea Res II 52:1300-1318

Mann K (1988) Production and use of detritus in various freshwater, estuarine and coastal marine ecosystems. Limnol Oceanogr 33:910-930

McQuaid CD, Payne AIL (1998) Regionalism in marine biology: the convergence of ecology, economics and politics in South Africa. J S Afr Sci 94:433-436

McQuaid CD, Lawrie SM (2005) Supply-side ecology of the brown mussel, Perna perna: an investigation of spatial and temporal variation in, and coupling between, gamete release and larval supply. Mar Biol 147:955-963

Megens L, van der Plicht J, de Leeuw JW (2001) Temporal variations in ${ }^{13} \mathrm{C}$ and ${ }^{14} \mathrm{C}$ concentrations in particulate organic matter from the southern North Sea. Geochim Cosmochim Acta 65:2899-2911

Menge B, Daley B, Lubchenco J, Sanford E, Dahlhoff E, Halpin P, Hudson G, Burnaford J (1999) Top-down and bottom-up regulation of New Zealand rocky intertidal communities. Ecol Monogr 69:297-330

Minagawa M, Wada E (1984) Stepwise enrichment of ${ }^{15} \mathrm{~N}$ along food chains: further evidence and the relation between ${ }^{15} \mathrm{~N}$ and animal age. Geochim Cosmochim Acta 8:1135-1140

Miyake Y, Wada E (1967) The abundance ratio of ${ }^{15} \mathrm{~N} /{ }^{14} \mathrm{~N}$ in marine environments. Rec Oceanogr Work Jpn New Ser 9: 32-53

Nielsen K, Navarrete S (2004) Mesoscale regulation comes from the bottom-up: intertidal interactions between con-

Editorial responsibility: Howard I. Browman (Associate Editor-in-Chief), Storebø, Norway sumers and upwelling. Ecol Lett 7:31-41

Rau GH, Sweeney R, Kaplan I (1982) Plankton ${ }^{13} \mathrm{C}:{ }^{12} \mathrm{C}$ ratio changes with latitude: differences between northern and southern oceans. Deep-Sea Res I 29:1035-1039

Rau GH, Takahashi T, DesMarais DJ (1989) Latitudinal variations in plankton $\delta^{13} \mathrm{C}$ : implications for $\mathrm{CO}_{2}$ and productivity in past oceans. Nature 341:516-518

Rau GH, Riebesell U, Wolf-Gladrow DA (1996) A model of photosynthetic ${ }^{13} \mathrm{C}$ fractionation by marine phytoplankton based on diffusive molecular $\mathrm{CO}_{2}$ uptake. Mar Ecol Prog Ser 133:275-285

Roberts MJ (2005) Chokka squid (Loligo vulgaris reynaudii) abundance linked to changes in South Africa's Agulhas Bank ecosystem during spawning and the early life cycle. ICES J Mar Sci 62:33-55

Rouillon G, Navarro E (2003) Differential utilization of species of phytoplankton by the mussel Mytilus edulis. Acta Oecol 24:S299-S305

Saino T, Hattori A (1980) ${ }^{15} \mathrm{~N}$ natural abundance in oceanic suspended particulate matter. Nature 283:752-754

Smith BN, Epstein S (1971) Two categories of ${ }^{13} \mathrm{C} /{ }^{12} \mathrm{C}$ ratios for higher plants. Plant Physiol 47:380-384

Stuart V (1982) Absorbed ration, respiratory costs and resultant scope for growth in the mussel Aulacomya ater (Molina) fed on a diet of kelp detritus of different ages. Mar Biol Lett 3:289-306

Stuart V, Field J, Newell R (1982) Evidence for absorption of kelp detritus by the ribbed mussel Aulacomya ater using a new ${ }^{51} \mathrm{Cr}$-labelled microsphere technique. Mar Ecol Prog Ser 9:263-271

Takai N, Onaka S, Ikeda Y, Yatsu A, Kidokoro H, Sakamoto W (2000) Geographical variations in carbon and nitrogen stable isotope ratios in squid. J Mar Biol Assoc UK 80: $675-684$

Vizzini S, Sara G, Michener RH, Mazzola A (2002) The role and contribution of the seagrass Posidonia oceanica (L.) Delile organic matter for secondary consumers as revealed by carbon and nitrogen stable isotope analysis. Acta Oecol 23:277-285

Ward JE, Levinton JS, Shumway SE, Cucci T (1998) Particle sorting in bivalves: in vivo determination of the pallial organs of selection. Mar Biol 131:283-292

Widdows J, Fieth P, Worrall CM (1979) Relationships between seston, available food and feeding activity in the common mussel Mytilus edulis. Mar Biol 50:195-207

Submitted: October 5, 2005; Accepted: December 15, 2005 Proofs received from author(s): July 13, 2006 